\title{
Teacher for talented students, a promoter of education for values
}

Tina Vrabie, Carmen Mihaela Crețu 


\title{
Teacher for talented students, a promoter of education for values
}

\author{
Tina Vrabie ${ }^{\mathrm{a}^{*}}$, Carmen Mihaela Creţu ${ }^{\mathrm{b}}$ \\ ${ }^{a, b}$ Doctoral School of Faculty of Psychology and Education Science, "Alexandru Ioan Cuza" University of Iaşi, Toma Cozma Street 3, 700704, Iaşi, \\ Romania \\ *Corresponding author: turiceanutina@yahoo.com
}

\section{Abstract}

\section{Keywords:}

talented students, good teacher, values promoting, moral values, education, teaching
The pedagogical story of what the good teacher's characteristics mean is different according to the research findings in the regular classroom situations and, respectively, in the inclusive educational settings. One of such inclusive settings addresses the talented students. They require special attention from teachers and school policy makers in order to fully develop their talent potential. Talented students have specific psycho-behavioural characteristics and special needs that require specialized, differentiated and personalised teaching.

Our work focuses on talented students' moral values and their intense socio-emotional characteristics and needs, such as the receptivity to moral perceptions, the sense of justice, altruism and orientation towards the fulfilment of ideals and the increased general sensitivity. This is the reason their teachers are highly challenged to profess and to promote the education for values.

The methodological approach of this article is based on gifted-education-for-values-orientated literature review. The work provides also a synthesis of the good teacher's competences emerged from the relevant evidence-based research data found in recent literature. We found that most of these research results underline the desirable characteristics and competencies of the talented students' teacher, as a moral beliefs promoter.

\section{Zusammenfasung}

\section{Schlüsselworte:}

begabte Studenten, guter Lehrer, Werte Förderung,

moralische

Vorstellungen,

Ausbildung, Lehre
Die pädagogische Geschichte von dem, was die Eigenschaften des guten Lehrers bedeuten, unterscheidet sich nach den Forschungsergebnissen in den regulären Unterrichtssituationen und jeweils in den inklusiven Bildungseinstellungen. Eines dieser inklusiven Bildungseinstellungen befasst sich mit den talentierten Studenten. Sie erfordern besondere Aufmerksamkeit von Lehrern und Schule-politischen Entscheidungsträger, um sich voll auf ihr Talent Potenzial zu entwickeln. Talentierte Studenten haben spezifische Psycho-Verhaltensmerkmale und besondere Bedürfnisse, die erfordern spezielle, differenzierte und individuelle Lehre.

Unsere Arbeit konzentriert sich auf den moralischen Werte der begabten Schüler und ihre intensive sozioemotionalen Eigenschaften und Bedürfnisse, wie die Empfänglichkeit für moralischen Wahrnehmungen, der Sinn für Gerechtigkeit, Altruismus und Ausrichtung auf die Erfüllung der Ideale und die erhöhte allgemeine Empfindlichkeit. Dies ist der Grund, ihre Lehrer sehr infrage gestellt werden, die Ausbildung für Werte zu bekennen und zu fördern.

Der methodologische Ansatz dieses Artikels basiert auf der Rezension der begabten-Bildung-für-Werte-orientierte Literatur. Die Arbeit stellt auch eine Synthese der Zuständigkeiten des guten Lehrers, entstand aus den relevanten evidenzbasierte in der neueren Literatur gefunden Forschungsdaten. Wir fanden, dass die meisten dieser Forschungsergebnisse die gewünschten Eigenschaften und Kompetenzen der begabten Schüler Lehrer unterstreichen, als Förderer der moralischen Überzeugungen.

\section{Introduction}

The actual legislative framework contains provisions regarding the cooperative relationship that should be established between schools and families.

The fact that teaching is a moral approach, which involves performing constructive educational activities based on values and moral principles, has been demonstrated by educational specialists a long time ago. Hansen (2001), in his review of a large number of studies on this subject, draws attention to the complexity of teaching as a moral activity (as cited in Willemse,
Lunenberg \& Korthagen, 2004, pp. 205-206). Thereby, the most difficult questions about the education for values that teachers have to answer are: In what ways should the teachers approach the extent of values in the school context? What methodology should teachers use in teaching students about values? What is the reference system to which they should relate in this regard? What are the most appropriate strategies which could be applied for the development of students' skills to put into practice the values they have internalized in the school context? 
In the attempt to identify the answer to all these questions, researchers in the field of education have studied the strategies and the practices used in school context for preparing students as moral agents, beyond achieving academic performance. The practices that Australian early years' teachers describe as important for teaching moral values consist in engaging students in morally-rooted activities, or with a heightened potential in shaping by way of demonstration, engaging a system of instructive frameworks, advancing in explicit contexts the values of social morality with meanings close to children's understanding. A powerful tool in teaching a moral code to gifted children is involving them in role playing situations (Johansson et. all, 2011), in which they could find a relation to their inner and outer social functioning. In order to be preoccupied and to adopt this sort of strategies and practices for promoting education for values the teacher himself has to have a desirable behaviour and therefore, implicitly, a set of values, a set that must invoke a deep implication, respect for the uniqueness of the student's being, commitment in the development of this uniqueness, and cooperation (Tirri, 2010 as cited in Brady, 2011). These recent researches construct the profile of the modern teacher, one who puts the student before and beyond him/ herself, who understands the role of education as a sum of relationships sustaining the student in challenging his/ her boundaries.

Starting from the premise of the complexity of teaching as a moral activity, we consider that the teacher profile is an essential aspect in approaching the extent of values in the school context. The teacher profile refers to the characteristics and competencies that he / she should possess in order to be a veritable professional and to contribute through his/ her work to the education for values.

The literature approaching the profile of the good teacher, in its attempts to identify the skills and attributes of this challenging educational factor, advanced a number of paradigms. The Behaviourism from 1960s to 1980s, defined a good teacher as being the teacher with good results as reflected in students' learning process; in the 1980s, which marked a shift in the perspective of analysis, to a qualitative assessment, the definition of a good teacher was considering the degree of awareness invested by the teacher in his/ her own values and goals as means for augmenting his/ her efforts in creating a productive teaching practice; in the 1990s the good teachers became mentors or facilitators for a learning process moving beyond the boundaries of the educational establishment into the virtual realm, where the diversity and richness of the information was coming to challenge the organizational qualities of the teacher (Tirri, 2008).

The study of the characteristics and competencies of a good teacher has progressed also over time from the research of these aspects in regular classroom situations to the research of these issues in inclusive educational settings. One of such settings addresses talented students, who require special attention from school policy makers and teachers in order to provide an environment able to develop the students' full talent potential. It is very important for talented students to benefit from specialized, differentiated and personalised teaching, from an optimal learning environment, and the attention of highly trained teachers who feel confident in their ability to respond appropriately to special needs of these children. The teachers of talented students have a significant influence on the curriculum and the learning environment; in this regard, there is a series of studies demonstrating that teachers who have the skills to design and implement educational programs for talented students are also those who contribute to the success of such initiatives. In general, the success of educational programs for talented students depends to a great extent on the support of teachers with a range of competencies in the training/ education of this category of students (Hansen \& Feldhusen, 1994).

In this paper, we present a value-oriented synthesis of relevant research that underlines the desirable characteristics and competencies of the talented students' teacher, as a moral beliefs promoter.

\section{Characteristics and competencies of a good teacher for talented students}

The definition of the good teacher becomes more nuanced when referring to the educational relationship with talented students. In this context, two avenues opened for the analysis of the intellectual and personal/ social qualities of a good teacher: one avenue is constructed by the teachers themselves, and the second one by the talented students. In both cases, the definition is further modulated by the cultural background and personal experiences of the interviewed. In the Israeli study carried out by Miligram (1979) the students strongly favoured the intellectual qualities of the teacher above his/ her personal/ social or creative valences. In another study developed by Maddux et al. (1985), in 
which the same instrument as in Miligram's study was engaged, the authors identified among the students a preference for the personal/ social characteristics of the teachers, favouring the social dimension; the intellectual and creative characteristics, while being relevant for the overall profile, were less relevant in delineating a productive teaching relationship (Tirri, 2008, p. 319).

Excellent teachers had to have also a strong and coherent philosophy and positive self-efficacy beliefs. The Scottish government has suggested five essential elements which an excellent teacher should possess:

- A positive attitude to students learning;

- An ability to communicate value to students;

- Good content knowledge and understanding;

- A teaching repertoire of many ways to impart content;

- Knowledge and understanding of connections across curricular areas (Alcorn 2004 as cited in MacDonald Grieve, 2010, p. 266).

To resume other aspects, we made a synthesis of the relevant studies found in the literature of giftedness on the desirable characteristics and competencies of a good teacher for talented students.

Bishop (1968) studied more than 200 teachers of talented students. He administered them psychological tests and observed their behaviour in the classroom and intensively interviewed their talented students also. Bishop concluded that teachers who were identified as exemplary are characterized by the following characteristics: superior intelligence; greater literary and cultural interests; higher achievement needs; stimulating and imaginative; they are student-centred in their teaching style; systematic and orderly.

In 1975 Bishop conducted another study regarding the profile of the teacher for talented students. He applied a series of questionnaires and interviews to: 1) successful teachers of talented students; 2) teachers selected randomly and 3) talented students. According to the results obtained the successful teachers for talented students should have the following characteristics: maturity and experience; high intelligence; intellectual, cultural and artistic interests; they should strive for high achievement; see things from student's point of view; they should be systematic, orderly, business-like; stimulating, imaginative, enthusiastic; they should encourage and sustain the students in advancing opinions, substantiating and defending them; the god teacher is the educational factor who becomes part of the challenges and the satisfactions a successful sharing in the class activities could bring.

Seeley (1979) carried out a research in the United States of America, in which principals, rectors and teachers/professors involved in talented students' education, from universities and pre-university education institutions were asked to assess the importance of desirable competencies of a good teacher for talented students, based on a given list. The results revealed that the competencies which have been assessed as the most important are: high cognitive skills in the field of teaching and asking questions; the ability to develop core curriculum change/ individualization strategies; the ability to implement special curricular development strategies; teaching and identification of talented students' abilities; student counselling skills.

Interesting findings on the desirable characteristics of talented students' teachers came out from the study developed by Maker in 1975. Based on a review of literature, he includes in his list only two minimal characteristics: 1) the ability to relate well to talented students and 2) openness to change. Less important but desirable are also considered to be the following characteristics: high intelligence, rich imagination, respect for the individual's potential, concerns about the teacher's responsibility towards his students, the belief that he/she can improve the self-image of his/her students (Maker, 1975 as quoted in Feldhusen, 1985, p. 87).

Hultgren and Seeley (1982), on the other hand, have reviewed thirteen studies and reports on the characteristics of a good teacher for talented students and present the following as the most commonly agreed/ preferred characteristics by researchers and specialists in psycho-pedagogy of excellence: maturity, experience, self-confidence; high intelligence; intellectual interests; performance orientation; they should show a positive attitude towards talented students; systematic and organized approaches; a well-developed sense of humour; the ability to facilitate learning; they should be very hard working; and possess extensive knowledge and expertise; belief in individual differences (Hultgren \& Seeley, 1982 as cited in Feldhusen, 1985, p. 88). 
According to Carmen Creţu, A.Y. Badwin (1989), based on the observations of a case study, proposes the following behavioural characteristics that the teacher should manifest in relation to talented students: maintaining a positive and close relationship with talented students to support the learning process; establishing numerous and qualitative verbal interactions with talented students; using time in a flexible way and connecting the timetable with the needs of these students; concentrating on a final goal, focusing mainly on students' productivity creativity; providing educational contexts appropriate to independent study interests; manifesting exemplary human behaviour (p. 149).

Another interesting research is the one carried out by Ann MacDonald Grieve (2010). The study targeted primary school teachers teaching Scotland, in an attempt to delineate the characteristics of the teacher associated with excellence. The questionnaire applied to the participants focused on a number of 44 characteristics of excellence which the respondents were requested to rate in the order of importance. The analysis revealed that the teachers had a clear perspective regarding the concept of excellence and described it based on a framework forged on two aspects, "personal qualities and interpersonal skills" (Grieve, 2010), intertwining in facilitating the access of the students to information and their discriminative comprehension. The subjects highly favoured those qualities which had the potential to give substance and their expectations regarding "a positive classroom ethos" (Grieve, 2010) and a relationship with the students based on communication skills, the accent on relationships, their development and their sustainability, the productive leadership. Nonetheless, the social skilled teacher must be characterized by friendliness and a deep understanding of the students' personalities in terms of similarities, but also differences. These social skills were considered instrumental in building a strong relationship.

Also, according to David W. Chan, in a recent study conducted in 2011 with 617 students of Chinese origin, nominated by teachers as talented, who evaluated the importance of 25 characteristics and 14 competencies that talented students' teachers should demonstrate; it has been revealed that all of the 39 characteristics and competences proposed for evaluation have been shown to be very important. The characteristics indicated by the students as the most important in this regard are: being imaginative, flexible, stimulating, innovative, facilitative, selfconfident, knowledgeable and considerate regarding the individual differences. As the study highlighted, the characteristics mentioned above construct a profile of a teacher defined by values and ideals of a higher order than one would expect to learn in a good teacher, without taking into account the characteristics and expectations of the student collection he/she must educate. The competencies indicated by the students to be the most important in this sense are, as Chan (2011) has underlined, creativity in the process of teaching, problem solving and developing/ engaging superior curriculum and teaching materials. On the other hand, the characteristics indicated by students to be less important in this respect are: a high intelligence, the ability to be less critical, more approachable and cooperative with the other members of the personnel and having control over one's personal life. The skills indicated by students to be less important in this sense are: career education and training other teachers for gifted programs.

\section{The Moral education for the talented students}

According to Bebeau, Rest and Narvaez (1999), morality is underlined by four basic component processes: moral sensitivity, moral judgment, moral motivation and moral character (quoted in Tirri, 2010, p. 59). Instrumental in analysing morality as a concept and a social structure of skills to be improved was considered the cognitive-development theory of Lawrence Kohlberg (1969), which most of the studies engaging in defining and deconstructing morality have employed. In measuring the development of moral judgment, the Defining Issues Test, developed by James Rest, in 1974, has become one of the most intensively used measures on this factor, although the research developed in the agegroup of the teenagers indicate that their dilemmas greatly deviate from the hypothetical dilemmas used by Kohlberg and his colleagues in order to assess the moral reasoning. While Kohlberg's dilemmas focus on subjects like ownership, public welfare and life and death, more general approaches of the social domain, in Yussen's study (1997), the subjects of the moral dilemmas expressed by teenagers most frequently are more focused, more individualized, circumscribing in general the interpersonal relations. The same propensity was identified within the studies conducted by Colangelo (1982) and Tirri (1996) on gifted teenagers (cited in Tirri, 2002).

Tirri (2010) presents in her paper the conclusions of some studies focused on the moral development of talented students, as following: (a) the students with high 
abilities have shown superior levels on the moral judgment factor compared to the students with average ability, nonetheless, "a high level of academic ability does not always predict a high level of moral judgment" (Narvaez, 1993; Tirri, 2011), (b) "intellectually gifted children appear to reach a relatively high stage of moral reasoning earlier than their chronological peers" (Karnes \& Brown), (c) the talented students are supposed to occupy a facilitating position in the process of achieving a mature moral thinking because of their faster intellectual accumulations (Andreani \& Pagnin, 1993), and (d) the gifted children demonstrate a marked ,maturity in moral development", regarding the selection of activities with a direct social constructive impact; the same advantage of maturity is to be seen in the ratings applied for misbehaviour (Terman, 1925, p. 60).

According to ethical competence theory morality can be taught. Teachers of the talented students are the ethical professionals who can contribute on the development of talented students from the perspective of education for values. They can do this through an individualized and personalized curriculum. The talented students have some special psycho-behavioural characteristics that enable them for example to" read" a moral situation more quickly and accurately in order to determine what role one might play or to prioritize their ethical ideals. This is why empirical studies also point to the need for teachers to discuss moral, spiritual and religious issues; especially those moral dilemmas that concern adolescents. Often talented adolescents are concerned about finding answers to questions such as: "Who am I?", "What is my role/ mission in the world? ", "What are the values that I should follow in my life?", "Does God exist?", "What is death?", "What happens after death?". Moral, spiritual and religious questions are part of talented students' concerns and the pedagogical task of education. Good and meaningful education for talented students should discus and debate questions like that (Tirri, 2007).

The didactics of the moral education for talented students should focus on approaching moral, spiritual and religious dilemmas that concern adolescents in general and talented adolescents in particular. Teachers of the talented students should be willing to discuss such issues in the classroom and to debate them with their students through a deliberative process. In this regard, there are some topics that should be considered, such as: interpretations of the moral issues; justifications of different actions in terms of morality; the profile of "a good teacher", "a good student", "a good human being"; indicators of commitment to moral ideals; all these in relation to real-life moral conflicts and the interpersonal relationships. In order to be effective in this approach the teacher of the talented students has to create a friendly and positive social environment for learning.

\section{Conclusions and discussions}

Based on the results of the studies presented above, we can conclude that the combination of the desirable intellectual qualities of a teacher and his/ her personal/ social qualities is the one that may influence the effectiveness of teaching and working with talented students, because in most cases the respondents mentioned aspects that concern both cognitive domain and affective (attitudes) domain. At the same time, the teacher of the gifted students must construct a friendly educational environment, in which the social factor would play a constructive role, facilitating the closeness between the act of teaching and the interaction outside the institutional realm. A positive, permeable, and studentoriented atmosphere will encourage the development at its fullest of the students' potential.

As we can see, one of the desirable characteristics of excellent teachers is "the ability to communicate value to students". From our point of view the reason why successful teachers for talented students are highly challenged to profess and to promote pedagogy for values is that talented students have specific psycho-behavioural characteristics, intense socio-emotional feelings, receptivity to moral perceptions, a sense of justice, altruism and orientation towards the fulfilment of ideals and an increased general sensitivity.

\section{Authors note:}

Vrabie Tina is Ph.D. Student, Faculty of Psychology and Education Sciences, "Alexandru Ioan Cuza" University of Iaşi.

Crețu Carmen Mihaela is Professor, Ph.D., Psychology Education Sciences, Faculty of Psychology and Education Sciences, "Alexandru Ioan Cuza" University of Iaşi. 


\section{References}

Ackerman, R.A., \& Donnellan, M.B. (2013). Evaluating selfreport measures of narcissistic entitlement. Journal of Psychopathology and Behavioral Assessment, 35(4), 460474.

Bishop, W.E. (1968). Successful Teachers of the Gifted. Exceptional Children, 34, 317-325.

Brady, L. (2011). Teacher Values and Relationship: Factors in Values Education. Australian Journal of Teacher Education, 36(2), 56-66.

Chan, D.W. (2011). Characteristics and Competencies of Teachers of Gifted Learners: The Hong Kong Student Perspective. Roeper Review, 33(3), 160-169.

Crețu, C. (1998). Curriculum diferențiat și personalizat. Ghid metodologic pentru învățătorii, profesorii și părinții copiilor cu disponibilități aptitudinale înalte. Iași: Editura Polirom.

Feldhusen, J.F. (1985). The Teacher of Gifted Students. Gifted Education International, 3(87), 87-93.

Hansen, J.B., \& Feldhusen, J.F. (1994). Comparison of trained and untrained teachers of gifted students. Gifted Child Quarterly, 38, 115-123.

Johansson, E., Brownlee, J., Cobb-Moore, C., Boulton-Lewis, G., Walker, S. \& Ailwood, J. (2011). Practices for teaching moral values in the early years: a call for a pedagogy of participation. Education, Citizenship and Social Justice, 6(2), 109-124.

MacDonald Grieve, A. (2010), Exploring the characteristics of 'teachers for excellence': teachers' own perceptions. European Journal of Teacher Education, 33(3), 265-277.

Mulhern, J.D., \& Ward, M. (1983). A collaborative program for developing teachers of gifted and talented students. Gifted Child Quarterly, 27, 152-156.

Seeley, K.R. (1979). Competencies for Teachers of Gifted and Talented Children. Journal for the Education of the Gifted, 3, 7-13.

Tirri, K. \& Nokelainen, P. (2007). Comparison of Academically Average and Gifted Students' Self-Rated Ethical Sensitivity. Educational Research and Evaluation: An International Journal on Theory and Practice, 13(6), 587-601.

Tirri, K. (2008). Who should teach the gifted students? Revista Espaňola de Pedagogia, 240, 315-324.

Tirri, K. (2010). Combining Excellence and Ethics: Implications for Moral Education for the Gifted. Roeper Review, 33(1), 59-64.

Tirri, K. (2002). Morality and High Ability. 69-77. Proceedings of the 8th Conference of the European Council for High Ability (ECHA), Rhodes, October 9-13, 2002.

Willemse, M., Lunenberg, M. \& Korthagen, F. (2004). Values in education: a challenge for teacher educators. Teaching and Teacher Education 21, 2005, 205-217. 